\title{
DEVELOPMENT OF E-LEARNING USING MOODLE APPLICATION ON MODEL PEMBELAJARAN SUBJECT IN EDUCATION TECHNOLOGY MASTER DEGREE UNIVERSITY OF MULAWARMAN
}

\author{
Zaenab Hanim, Karina Octavira, Rahmat Soe'oed \\ Mulawarman University \\ zaenab.hanim@fkip.unmul.ac.id, orin.for.karina@gmail.com, rahmatsoeoed@ffkip.unmul.ac.id
}

\begin{abstract}
Abstrak
Penelitian ini dilakukan untuk mengembangkan media pembelajaran E-Learning menggunakan Aplikasi Moodle pada mata kuliah Model Pembelajaran untuk mahasiswa Magister Teknologi Pendidikan Universitas Mulawarman. Tujuan dalam penelitian ini, mengembangkan prosedur pengembangan E-Learning dengan aplikasi Moodle untuk mata kuliah Model Pembelajaran di Magister Teknologi Pendidikan Universitas Mulawarman, Jenis penelitian yang diterapkan adalah penelitian pengembangan menggunakan model pengembangan ADDIE. Penelitian ini diujicobakan pada mahasiswa angkatan 2017 Magister Teknologi Pendidikan Universitas Mulawarman sebagai sasaran penelitian. Data divalidasi oleh uji ahli media, ahli materi, uji perorangan, uji kelompok kecil dan uji lapangan dengan menggunakan angket dan dianalisis secara kualitatif, kuantitatif dan metode-metode statistik. Hasil penelitian menunjukkan adanya pengembangan E-Learning berupa produk pengembangan.
\end{abstract}

Kata kunci: Pengembangan, E-Learning, Moodle, Model Pembelajaran

Abstract

This research was conducted to develop E-Learning Instructional Media using Moodle on Model Pembelajaran subject for Education Technology students of Master's Degree in Mulawarman University. The purpose of this research are to develop the E-learning procedure development using Moodle on Model Pembelajaran subject for Education Technology students of Master's Degree in Mulawarman University. This type of research is the Research and Development using ADDIE development model. This research is experimented to the 2017 generation Education Technology Master's Student in University of Mulawarman. The data are validated by media experts, content experts, individual testing, small group testing and field tests using a questionnaire, then the data were analyzed with qualitative, quantitative and another statistical analysis methods. The research finding shown an instructional product using E-learning.

Keyword : Development, E-Learning, Moodle, Model Pembelajaran

\section{PENDAHULUAN}

Kegunaan aplikasi E-Learning adalah untuk mendukung pengajaran guru dan meningkatkan pemahaman siswa. Akan tetapi, metode pembelajaran konservatif masih dipraktekkan di kelas dan penggunaan pembelajaran hampir tidak ada. Alasan utama untuk ini adalah kurangnya infrastruktur, fasilitas, dan teknologi terkait yang memungkinkan penggunaan TIK dan E-Learning secara bermakna. Studi di seluruh dunia menunjukkan bahwa kekurangan di atas tidak akan mendorong pembelajaran menggunakan TIK atau E-Learning.

E-Learning membawa pengaruh terjadinya proses transformasi pendidikan konvensional ke dalam bentuk digital, baik secara isi (contents) dan sistemnya. Saat ini, konsep E-Learning sudah banyak diterima oleh masyarakat dunia yang dibuktikan dengan maraknya implementasi $E$ Learning khususnya di lembaga pendidikan.
Menurut Sofan Amri (2013), kecenderungan untuk mengembangkan E-Learning sebagai salah satu alternatif pembelajaran di berbagai lembaga pendidikan dan pelatihan semakin meningkat sejalan dengan perkembangan di bidang teknologi komunikasi dan informasi yang menunjang penyelenggaraan E-Learning. Rosenberg (2001) juga menambahkan ada tiga pergeseran dalam proses pembelajaran akibat perkembangan teknologi komunikasi yaitu pergeseran dari ruang kelas ke dimana dan kapan saja, pergeseran dari kertas ke online, dan pergeseran fasilitas fisik ke fasilitas jaringan kerja..

Berdasarkan penelitian Veronica (2016), ELearning telah mengubah metode dalam penyampaian materi pembelajaran serta menyesuaikan pada karakteristik proses interaksi antara pengajar dan peserta didik. E-Learning juga memberikan pemberian tugas dimana kondisi keharusan bertatap muka antara pengajar dan 
peserta didik menjadi berkurang sehingga hal ini dapat menjadi sebuah pilihan dalam metode pembelajaran. Pengajar dapat menemukan dan mencari perangkat fitur pada sistem yang lebih memudahkan dalam menjalankan metode pembelajarannya baik dalam pengajaran secara langsung ataupun online. Aplikasi Moodle dapat meningkatkan komunikasi antara pengajar dan peserta didik serta meningkatkan kepuasan peserta didik terhadap pelajaran yang diterimanya. Mahasiswa dapat bertanya pada dosen melalui online. Moodle memudahkan pengajar dalam menyediakan informasi dan pembelajaran lain yang menunjang modul mata pelajaran atau mata kuliah. Melalui ujian dan latihan-latihan yang disediakan dalam sistem, peserta didik dapat melihat peluang dari hasil ujian dan latihan mereka, mengetahui kekurangan mereka agar dapat mempelajari kembali hal-hal yang menjadi kesulitan untuk dipahami.

Dari hasil observasi yang dilakukan di lingkungan Magister Teknologi Pendidikan Universitas Mulawarman bahwa pada mata kuliah Model Pembelajaran di Magister Teknologi Pendidikan, pelaksanaan kegiatan belajar mengajar masih dilakukan secara konvensional. Mata kuliah tersebut banyak menekankan pada simulasi, proses dan akan lebih mudah dipahami jika menggunakan sebuah media pembelajaran. Pada jenjang pendidikan ini, keaktifan peserta didik (mahasiswa) idealnya lebih diutamakan dalam mempelajari dan mencari sumber-sumber belajar untuk memenuhi standar ketuntasan mata kuliah tersebut, terutama karena hasil proses belajar pada jenjang magister diharapkan dapat membentuk sikap seorang pendidik yang profesional dan berkualitas.

Berdasarkan uraian latar belakang masalah yang dikemukakan di atas, maka fokus permasalahan yang berhubungan dengan pembelajaran mata kuliah Model Pembelajaran yaitu penggunaan E-Learning di Magister Teknologi Pendidikan Universitas Mulawarman belum dioptimalkan untuk seluruh mata kuliah, adanya keterbatasan penggunaan perangkat pembelajaran di lingkungan kampus dan harus dilakukan di luar lingkungan kampus, para pengajar belum banyak yang memanfaatkan $E$ -
Learning, mayoritas metode pembelajaran dilakukan secara konvensional melalui ceramah atau slide (Power Point), dan prosedur pengumpulan tugas yang masih berupa E-mail atau cetakan sebagai media untuk mengumpulkan tugas tersebut.

Berdasarkan uraian yang telah dikemukakan di atas, rumusan masalah dalam penelitian pengembangan ini antara lain 1) Bagaimana prosedur E-Learning untuk mata kuliah Model Pembelajaran dengan menggunakan aplikasi Moodle? 2) Bagaimana keefektifan E-Learning dengan aplikasi Moodle pada mata kuliah Model Pembelajaran? 3) Bagaimana ketertarikan mahasiswa terhadap E-Learning dengan aplikasi Moodle pada mata kuliah Model Pembelajaran?

Oleh karenanya, untuk menjawab rumusan masalah tersebut, tujuan penelitian ini antara lain : 1) Untuk mengembangkan prosedur pengambangan E-Learning dengan aplikasi Moodle untuk mata kuliah Model Pembelajaran di Magister Teknologi Pendidikan Universitas Mulawarman, 2) untuk mengetahui keefektifan pembelajaran mahasiswa pada mata kuliah Model Pembelajaran di Magister Teknologi Pendidikan Universitas Mulawarman, dan 3) untuk menguraikan ketertarikan mahasiswa pada pembelajaran dengan E-Learning yang dikembangkan pada mata kuliah Model Pembelajaran di Magister Teknologi Pendidikan Universitas Mulawarman.

\section{METODE}

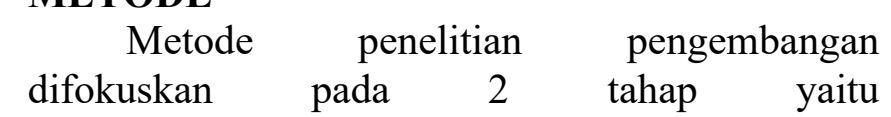
tahap preliminary dan tahap formative evaluation yang meliputi self evaluation, prototyping (expert reviews dan one-to-one, dan small group), serta field test. I Wayan Santyasa (2009) [8] menyebutkan bahwa pada tahap ini, peneliti akan menentukan tempat dan subjek penelitian seperti dengan cara menghubungi pihak yang berkepentingan di tempat yang akan menjadi lokasi penelitian. Selanjutnya peneliti akan mengadakan persiapan-persiapan lainnya, seperti mengatur jadwal penelitian dan prosedur kerja sama dengan guru kelas yang dijadikan tempat penelitian. 
Dalam penelitian pengembangan ini, model yang digunakan dalam pengembangan E-learning menggunakan Aplikasi Moodle untuk mata kuliah Model Pembelajaran adalah model ADDIE. Model pengembangan ini dipilih karena Salah satu fungsinya ADDIE yaitu menjadi pedoman dalam membangun perangkat dan infrastruktur program pelatihan yang efektif, dinamis, sistematis dan mudah untuk dipahami. Tahapan penelitian pengembangan pada model ADDIE antara lain: (1) Analisis (Analysis), (2) Desain/perancangan (Design), (3) Pengembangan (Development), (4) Implementasi (Implementation), dan (5) Evaluasi (Evaluation). Kelima tahap prosedur pengembangan tersebut dapat dilihat pada bagan tahap-tahap pengembangan sebagai berikut.

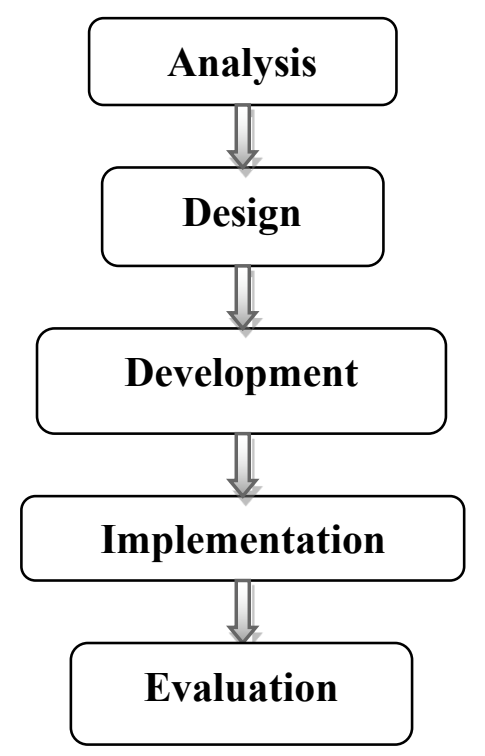

\section{Gambar 1. Model Pengembangan ADDIE}

Secara rinci, Kukuh Andri Aka (2017) [9] menjabarkan tahapan dari model pengembangan ADDIE pada penelitian ini, antara lain :

1) Tahap 1 Analisis (Analyze). Hasil analisis diambil berdasarkan observasi pada lapangan, ditemukan fakta bahwa karakteristik mahasiswa di Magister Teknologi Pendidikan Universitas Mulawarman merupakan mahasiswa yang sudah tidak asing lagi dengan perkembangan teknologi. Dalam menunjang kebutuhan belajarnya, mahasiswa terbiasa membawa laptop atau notebook dan menjadikan perangkat tersebut sebagai sumber belajar selain dosen, misalnya dengan memanfaatkan fasilitas jaringan internet untuk mencari bahan-bahan belajar dan tugas. Selain itu, metode pembelajaran di Magister Teknologi Pendidikan Universitas Mulawarman menunjukkan bahwa sangat cocok untuk dikembangkan media pembelajaran E-learning menggunakan Aplikasi Moodle. Fasilitas yang menunjang di lingkungan kampus antara lain etersediaan jaringan hotspot kampus untuk mendukung pencarian informasi menggunakan notebook atau laptop. Sebagai sampel mata kuliah yang akan dijadikan bahan dalam E-Learning, dipilih mata kuliah Model Pembelajaran karena dalam mata kuliah tersebut diperlukan pemahaman secara konsep dan praktik, sehingga memerlukan suatu media pembelajaran yang secara kompleks memberikan pemahaman terhadap dua hal tersebut. Aplikasi Moodle dapat menjawab kebutuhan tersebut melalui fitur-fitur yang tersedia di dalamnya.

2) Tahap 2 Perancangan (Design). Hal yang harus dilakukan dalam tahap desain ini ialah merumuskan tujuan pembelajaran yang SMAR (specific, measurable, applicable, dan realistic). Selanjutnya menyusun tes, dimana tes tersebut harus didasarkan pada tujuan pembelajaran yang telah dirumuskan tadi. Kemudian menentukan strategi pembelajaran media dan yang tepat untuk mencapai tujuan tersebut. Selain itu, dipertimbangkan pula sumber-sumber pendukung lain, misalnya sumber belajar yang relevan, lingkungan belajar, dan lain-lain.

3) Tahap 3 Development (pengembangan) adalah proses mewujudkan blue-print dari desain menjadi kenyataan. Artinya, jika dalam desain diperlukan suatu software berupa multimedia pembelajaran, maka multimedia tersebut harus dikembangkan. Satu langkah penting dalam tahap pengembangan adalah uji coba sebelum diimplementasikan. Langkah 
pengembangan meliputi kegiatan membuat, membeli, dan memodifikasi bahan ajar. tahap ke-3 ini merupakan kegiatan pengumpulan bahan atau materi pelajaran yang diperlukan untuk pembuatan produk seperti: materi pokok dan aspek pendukung (teks, gambar, animasi, audio dan video). Tahap ini juga merupakan perakitan media/ penggabungan seluruh bahan seperti materi pelajaran, gambar, animasi dan teks.

4) Tahap 4 Implementation (implementasi), adalah langkah nyata untuk menerapkan sistem pembelajaran yang sedang kita buat. Artinya, pada tahap ini semua yang telah dikembangkan diinstal atau diatur sedemikian rupa sesuai dengan peran atau fungsinya agar bisa diimplementasikan. Implementasi atau penyampaian materi pembelajaran merupakan langkah keempat dari model desain sistem pembelajaran ADDIE. Penerapan E-Learning menggunakan aplikasi Moodle dikembangkan di Magister Teknologi Pendidikan Universitas Mulawarman, untuk mengetahui respon mahasiswa terhadap E-Learning yang dikembangkan dari segi kemenarikannya dan keefektifannya.

5) Tahap 5 Evaluation (evaluasi), yaitu proses untuk melihat apakah sistem pembelajaran yang sedang dibangun berhasil, sesuai dengan harapan awal atau tidak. Sebenarnya tahap evaluasi bisa terjadi pada setiap empat tahap di atas, tujuannya untuk kebutuhan revisi. Evaluasi merupakan langkah terakhir dari model desain sistem pembelajaran ADDIE. Evaluasi yang dilakukan bertujuan untuk mengetahui efektifitas dan ketertatikan mahasiswa terhadap media pembelajaran yang dikembangkan serta membandingkan kelebihan produk dengan model pembelajaran yang sebelumnya diterapkan di kelas.

Hasil dari penelitian pengembangan ini diuji tingkat validitas dan keefektifannya. Tingkat validitas media pembelajaran diketahui melalui hasil analisis dari : a) validasi oleh ahli materi mata kuliah, dan ahli desain multimedia, b) uji coba yang dilakukan meliputi uji perorangan, uji kelompok kecil, dan uji coba lapangan. Jenis data pada penelitian ini dikelompokkan menjadi dua, yaitu data kualitatif dan data kuantitatif. Data Kualitatif dihimpun dari hasil penilaian, masukkan, tanggapan, kritik, dan saran perbaikan melalui angket dari para ahli dan mahasiswa, sedangkan data kuantitatif yang dikumpulkan melalui angket tertutup yaitu hasil dari (1) penilaian ahli isi bidang studi atau mata pelajaran, ahli desain pembelajaran dan ahli media pembelajaran, (2) review siswa (tahap uji perorangan, tahap uji kelompok kecil, dan tahap uji lapangan).

\section{HASIL DAN PEMBAHASAN}

Produk yang dikembangkan dalam penelitian ini adalah media pembelajaran E-learning menggunakan Aplikasi Moodle. Saat ini, penelitian telah memasuki tahapan Development atau pengembangan yakni mewujudkan desain media pembelajaran dalam suatu aplikasi yang akan digunakan baik oleh pengajar maupun peserta didik. Aplikasi yang diperlukan dalam ELearning ialah Moodle versi 3.5 dan XAMPP versi 3.2, dimana akan dibuat secara offline terlebih dahulu sebelum dapat diakses secara online.

Tahapan pengembangan dilakukan melalui proses menganalisis kebutuhan dalam media pembelajaran dan mendesain tampilan, tata letak, serta alur-alur proses dalam media pembelajaran tersebut. Hal ini mnjadi penting agar media pembelajaran yang dibuat sesuai dengan rancangan dan analisis kebutuhan yang telah dilakukan. Untuk menguji kualitas, E-learning menggunakan aplikasi Moodle akan dilakukan uji coba materi, uji coba desain, uji perorangan dan uji kelompok besar dan kecil. Berikut adalah tampilan dari pengembangan E-Learning menggunakan
Moodle. 


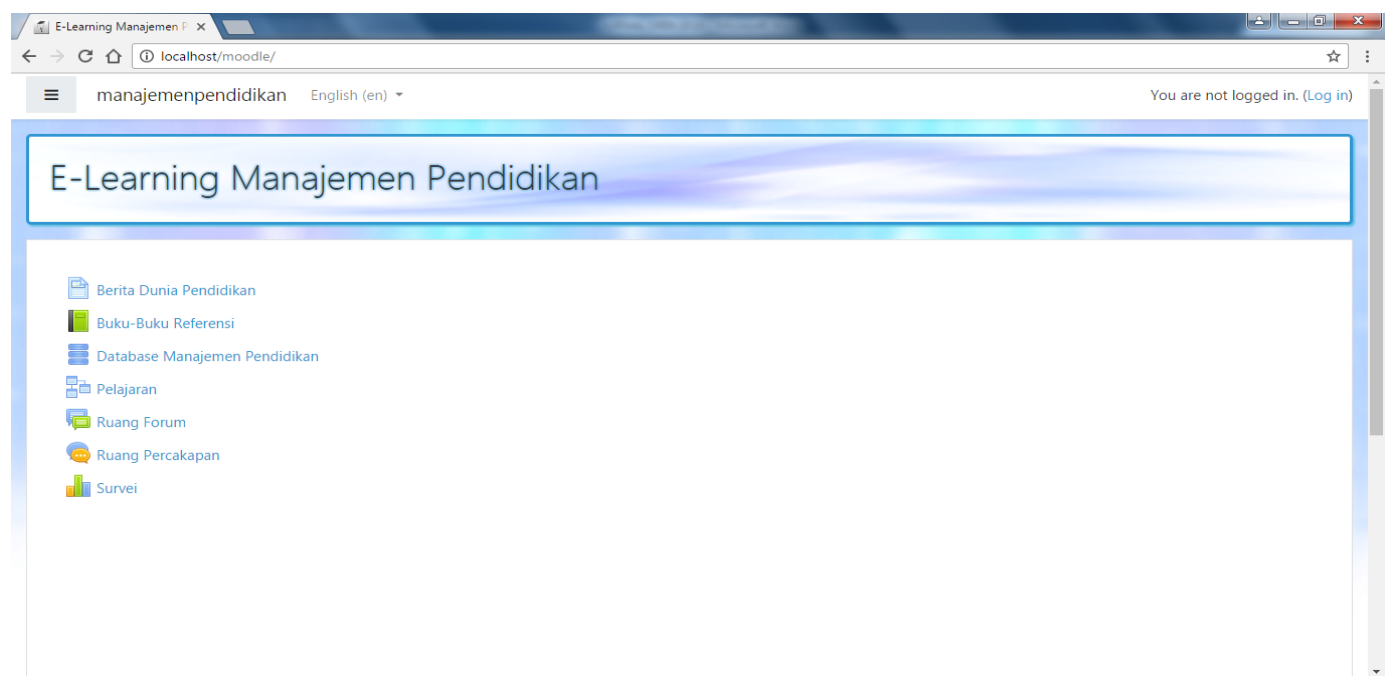

Gambar 2. Halaman Utama

Sebelum login, E-Learning yang dimuat dalam browser akan mengarahkan pengguna pada Halaman Utama, dimana terdapat beberapa menu seperti Berita, Buku Referensi, Database, Mata
Pelajaran/Perkuliahan, Forum dan Percakapan, serta fitur Survei. Untuk dapat mengakses menumenu tersebut, pengguna harus melakukan Login terlebih dahulu (Link sebelah kanan atas).

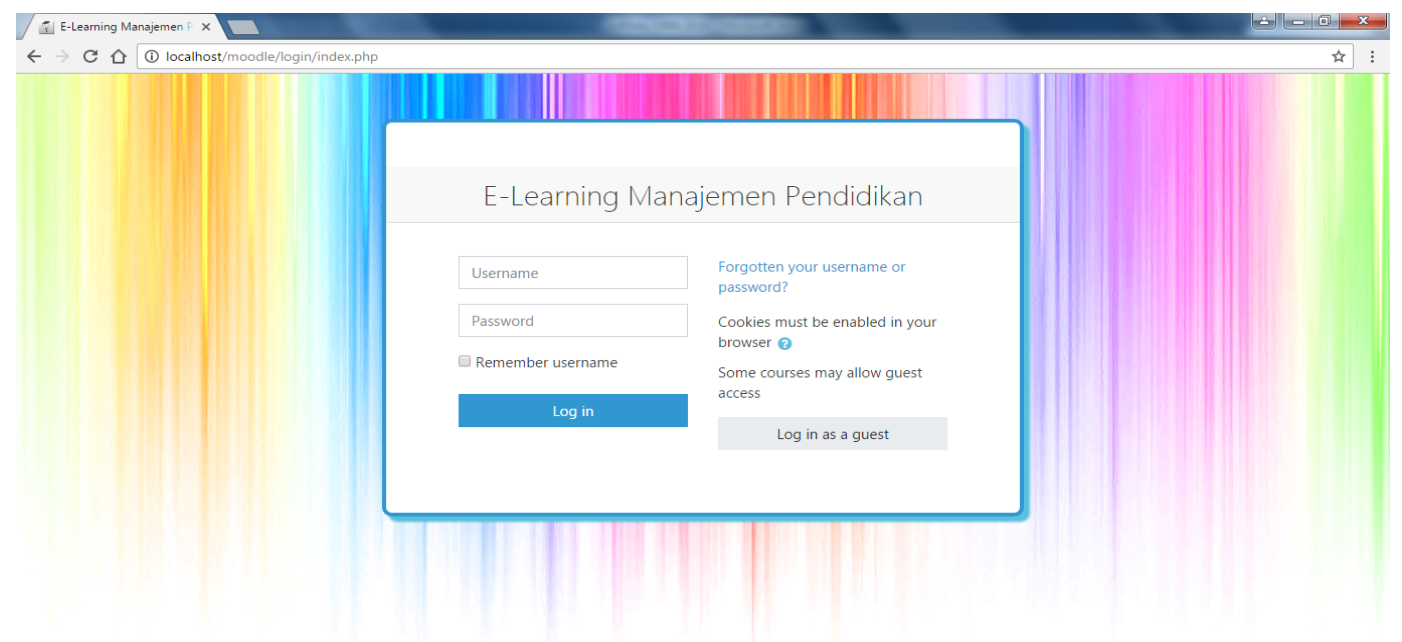

Gambar 3. Halaman Login

Halaman Login berfungsi sebagai pintu akses pengguna dengan media pembelajaran online. Pada aplikasi Moodle, pengguna bisa bertindak sebagai admin dan mengatur konten-konten yang tersedia di dalam aplikasi. Admin harus memasukkan username dan password sebagaimana yang telah didaftarkan pada proses awal instalasi Moodle. Sedangkan pengguna selain admin dapat masuk ke dalam sistem aplikasi melalui tombol pilihan "Login as a guest". Pengguna dapat melakukan Login dengan username dan password jika telah meregistrasikan dirinya kepada Admin User. 


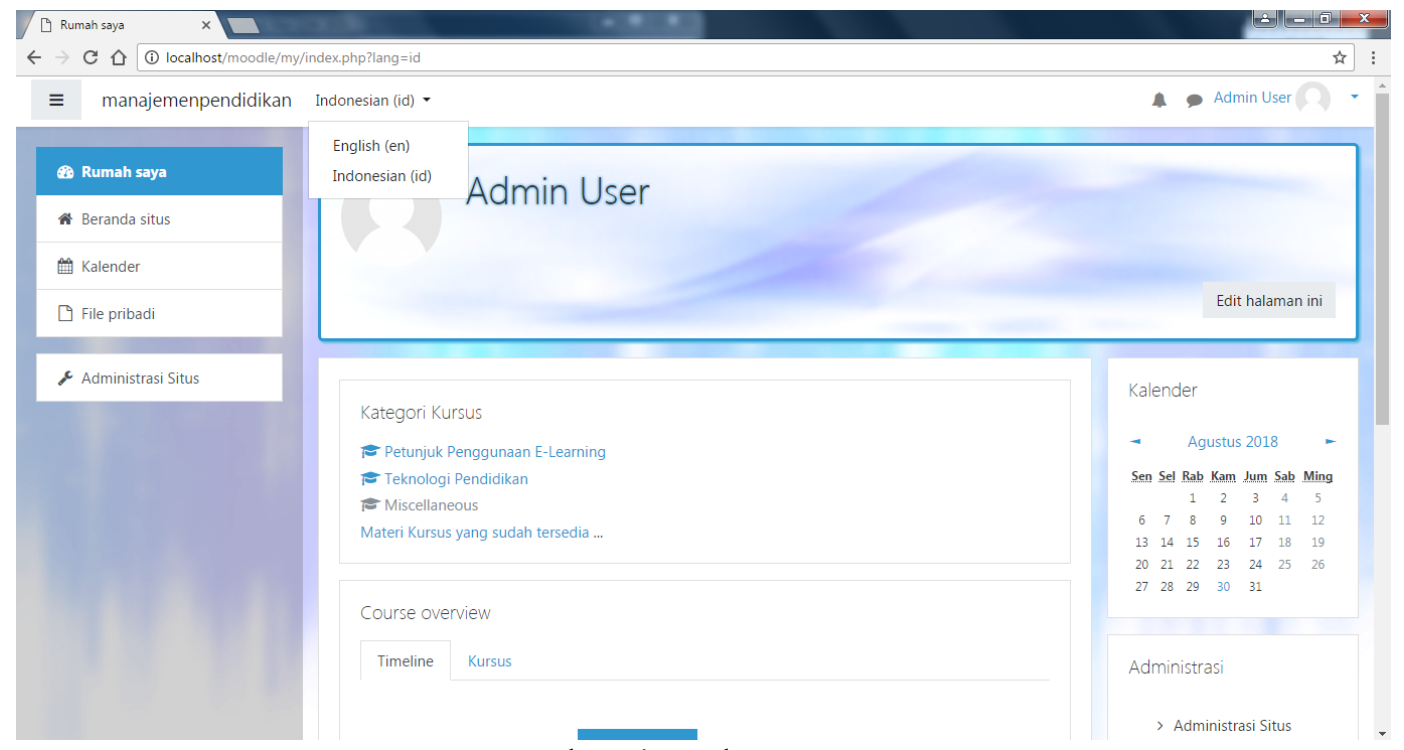

Gambar 4. Halaman User

Setelah proses Login, pengguna akan masuk pada halaman User, dimana pada halaman tersebut terdapat kategori berupa tautan tentang Petunjuk Penggunaan E-Learning dan pilihan jurusan (dalam penelitian ini baru 1 Jurusan yang dimasukkan yaitu Teknologi Pendidikan). Petunjuk Penggunaan E-Learning berisi halaman tentang cara-cara menggunakan E-Learning secara umum, terutama bagi pengguna siswa atau mahasiswa, untuk dapat melihat materi-materi yang disediakan dalam sistem E-Learning. Sedangkan tautan Teknologi Pendidikan berisi tentang materi-materi mata kuliah serta sumber- sumber belajar lainnya yang ada di jurusan Teknologi Pendidikan.

Admin User memiliki hak untuk mengatur konten dalam sistem E-Learning yang dibuat, salah satunya adalah menambah kursus atau mata kuliah dalam kategori (Gambar 5). Pada penelitian ini, kategori diibaratkan jurusan dalam Magister Teknologi Pendidikan yakni Teknologi Pendidikan, Sedangkan istilah kursus digunakan untuk mata kulah yakni Model Pembelajaran yang didalamnya akan diunggah materi-materi yang akan dipelajari mahasiswa.

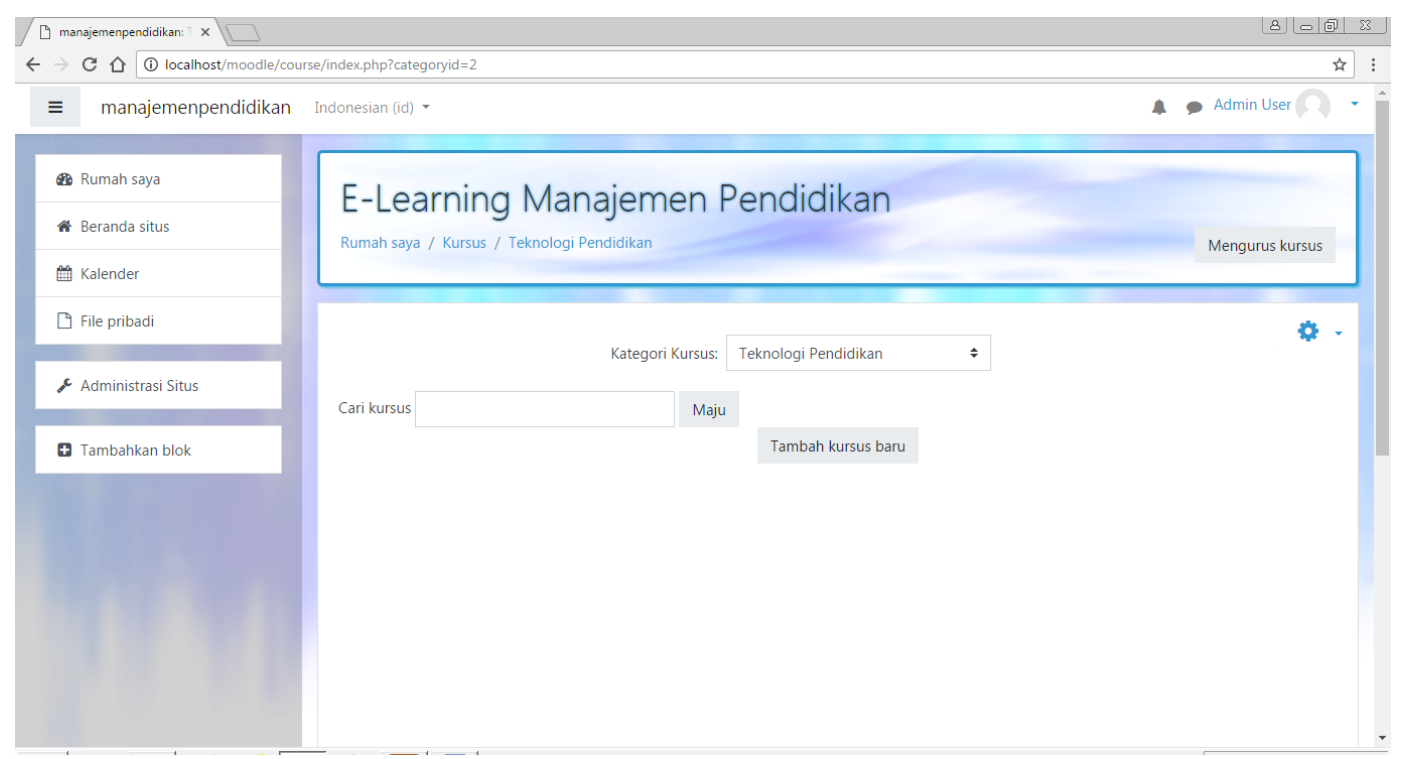

Gambar 5. Halaman untuk Menambahkan Kursus/Materi Kuliah 
Pada Gambar 6, adalah tampilan sistem ELearning dengan menggunakan Moodle yang telah diunggah materi mata kuliah di dalamnya (topic). Pada topic tersebut terdapat dua file yang dapat dilihat mahasiswa yaitu materi dengan topik Model Pembelajaran Kooperatif dan Satuan Acara Perkuliahan topik tersebut yang disajikan dalam format .pdf. Mahasiswa dapat melihat secara langsung melalui layar komputer (embed) atau diunduh (download) untuk keperluan perkuliahan. Konten dalam masing-masing topik diatur oleh admin user dengan menyesuaikan kebutuhan dari mahasiswa dalam proses pembelajarannya.

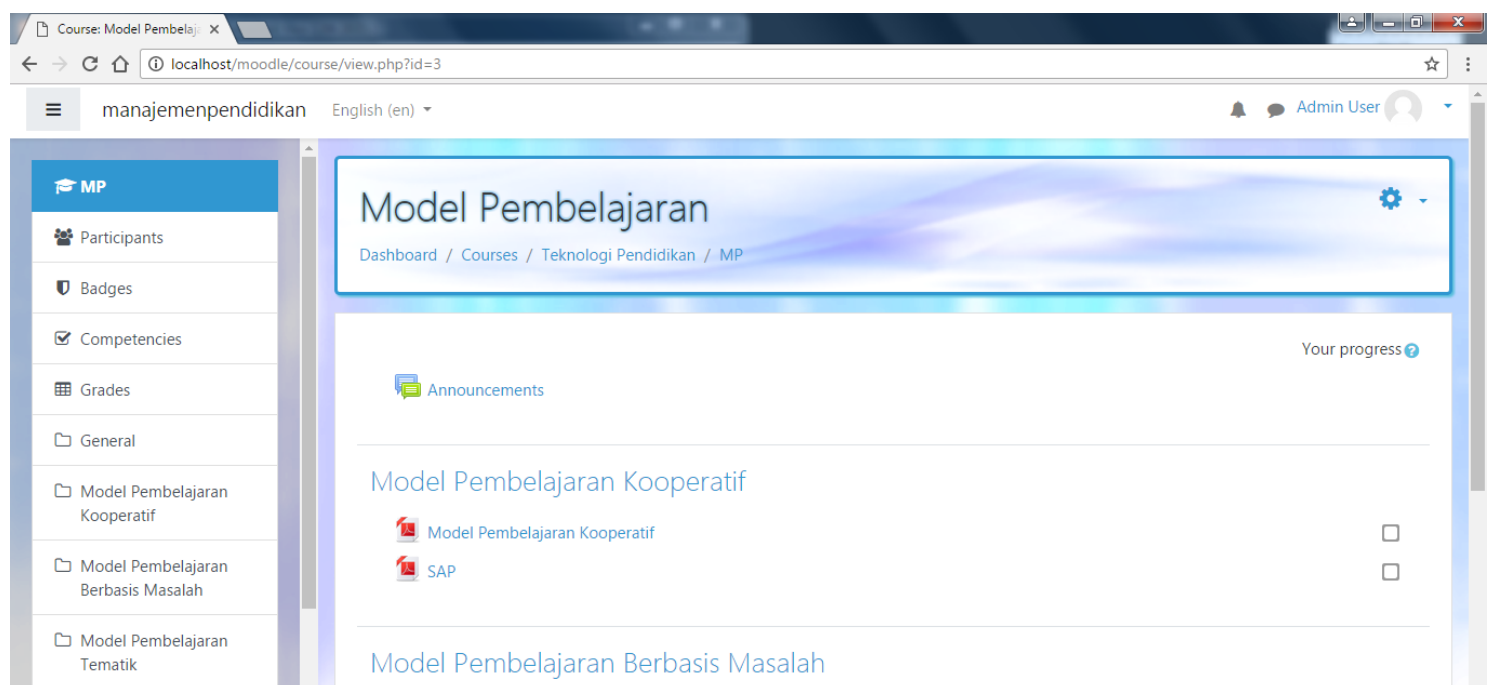

Gambar 6. Halaman Course Materi Model Pembelajaran

Pada pilihan dalam topik Model Pembelajaran Kooperatif, terdapat file materi dan SAP dalam bentuk PDF. Jika di klik, maka secara otomatis, file yang dipilih akan muncul di layar komputer dan dapat dimanfaatkan oleh mahasiswa sebagai sumber belajar (Gambar 7). Materi yang diunggah dalam sistem adalah materi yang telah ditentukan oleh peneliti sebagai bahan penelitian dan akan divalidasi oleh ahli materi untuk keperluan tahapan penelitian selanjutnya.

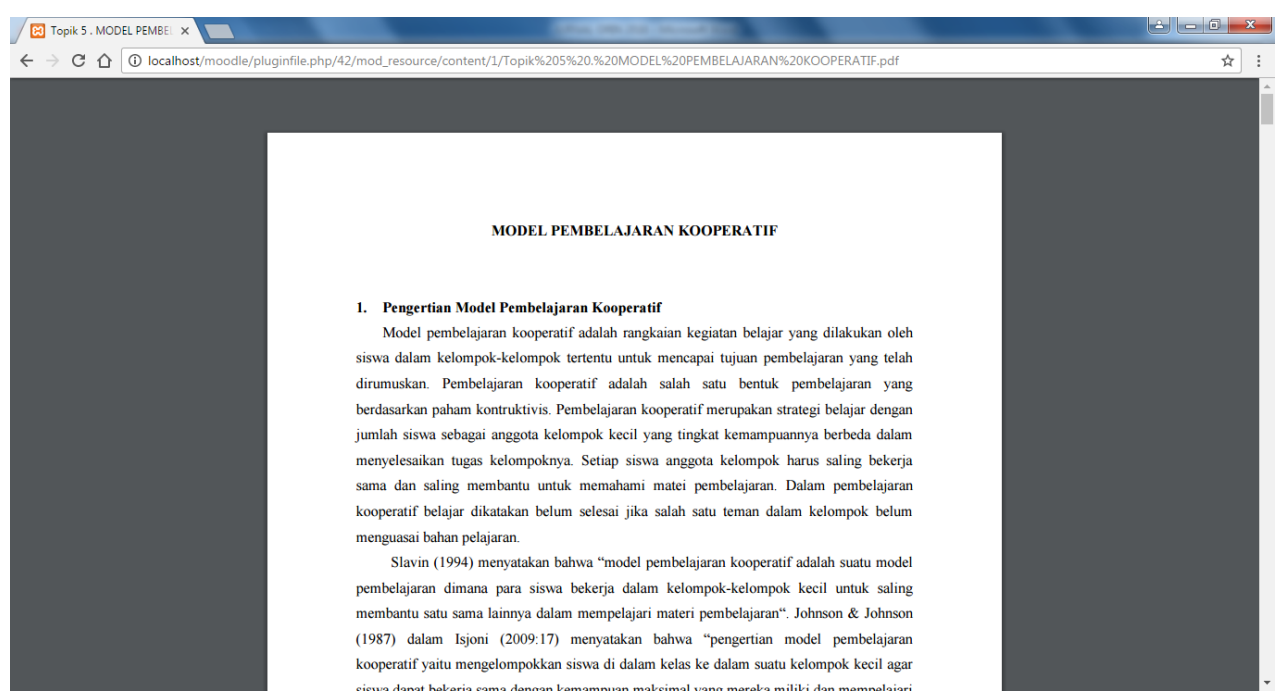

Gambar 7. Halaman Materi Model Pembelajaran dalam format PDF 


\section{KESIMPULAN}

Berdasarkan rumusan masalah Bagaimana prosedur E-Learning dengan aplikasi Moodle pada mata kuliah Model Pembelajaran, proses pengembangan yang sedang berjalan penelitian ini, dapat diambil kesimpulan bahwa produk yang dikembangkan adalah media pembelajaran berupa E-Learning menggunakan Aplikasi Moodle sebagai aplikasi perantaranya. Tahapan pengembangan yang digunakan adalah ADDIE (Analyze, Design, Development, Implementation, dan Evaluation). Saat ini untuk tahapan yang telah dan masih dilanjutkan adalah tahapan Development (Pengembangan) dimana sebelum tahapan tersebut telah dilakukan analisis terhadap kebutuhan dalam proses pembelajaran dan design berupa alur jalan program. Hal tersebut bertujuan untuk mempermudah pengaturan tampilan tata letak konten-konten yang diunggah ke dalam media.

\section{DAFTAR PUSTAKA}

Misut, Martin, et al. 2015. Measuring of Quality in Context of E-Learning. Elsevier Ltd Procedia Soscial and Behaviour Science, P.312

Amri, Sofan. 2013. Pengembangan dan Model Pembelajaran dalam K13. PT. Prestasi Pusakaraya : Jakarta, P. 151-152
Rosenberg, M.J. 2001. E-Learning : Strategies for Delivering Knowlegde in the Digital Age. McGraw-Hill Professional, P.211

Herayanti, Lovy, et al. 2017.'Pengembangan Media Pembelajaran Berbasis Moodle pada Matakuliah Fisika Dasar".Cakrawala Pendidikan Tahun XXXVI, No.2, P.211

Ivanova, Veronica, et al. 2016. Active Learning Approach in Moodle for the Organization of Student's Self-Study Practice-Based Learning Activities. EDP Sciences. P. 1

Fithri, Diana Laily. 2014. "Analisa dan Perancangan E-Learning Pembelajaran Grammer untuk meningkatkan Potensi Siswa”. Jurnal SIMETRIS Vol. 5 Nomor 1 April 2014, P. 68

Turino, dkk. 2009. "E-Learning Bahasa Inggris Berbasis Web". Jurnal Teknologi Informasi. Volume 5 Nomor 2. ISSN 1414-9999.

Santyasa, I Wayan. 2009. Metode Penelitian Pengembangan dan Teori Pengembangan Modul. Singaraja (PDF)

Aka, Kukuh Andri. 2017. Model-Model Pengembangan Bahan Ajar. http://belajarpendidikanku.blogspot.co.id, diakses pada 9 November 2017 